\title{
Research trends in agricultural science: A global perspective
}

\author{
Anil Sagar*, Basavaraj Shivappa Kademani and Karanam Bhanumurthy \\ Scientific Information Resource Division, Bhabha Atomic Research Centre, Mumbai, India
}

\begin{abstract}
This paper attempts to highlight quantitatively and qualitatively the growth and development of global agricultural science publication output and citations as per Web of science during 1993-2012. The objective of this study was to perform a scientometric analysis of all agricultural science research publications in the world. The parameters studied include growth of publications and citations, continent-wise distribution of publications and citations, country-wise distribution of publications, publication efficiency index, domain-wise distribution of publications and citations, specialization index, variation of average impact factor in agricultural science sub-domains, language-wise distribution of publications, distribution of high frequency keywords, identification of highly cited publications and highly preferred journals.
\end{abstract}

Keywords: Agricultural economics and policy, agricultural engineering, agricultural science, agriculture-multidisciplinary, Agronomy, dairy and animal sciences, publication efficiency index, publication productivity, quality research, R and D trend, scientometrics

\section{INTRODUCTION}

The human civilization began with agriculture. Our nomadic ancestors who depended on hunting and fishing for living slowly learnt to grow their own food. This metamorphosed the human society forever. Villages, towns and cities begin to flourish. This led man to advance in several branches of knowledge. In spite of several advancements in identifying several high yield crops and record production of agricultural produce, a significant portion of the population continue to suffer from hunger and malnutrition. The rate of growth in agricultural production is declining; world grain reserves have fallen to record lows; the demand for imported grain is increasing; and commitments of aid to agricultural

*Address for correspondence:

E-mail: asagar@barc.gov.in

\begin{tabular}{|l|l|}
\hline \multicolumn{2}{|c|}{ Access this article online } \\
\hline Quick Response Code: & \\
\cline { 1 - 1 } & Website: \\
\hline & www.jscires.org \\
\cline { 2 - 3 } & DOI: \\
\hline
\end{tabular}

development have decreased. This against a backdrop of expanding world population, intensifying demands on agricultural resources, and a growing recognition that the agri-food system is not sustainable. In addition, there is a lot of food is wasted because of lack of proper storage, preservation and distribution system in many countries. Therefore, it is high time that immediate necessary action has to be initiated at the national and international level to tackle this serious problem of food insecurity and make the world free from hunger.

Nearly 1 billion people-one out of six globally-lack access to adequate food and nutrition. By 2050, the global population will surpass 9 billion people, and demand for agricultural products is expected to double. Simultaneously, the world's agricultural systems will be increasingly challenged by water scarcity, climate change and volatility, raising the risk of production shortfalls. Substantial gains in agricultural productivity can be realized through investment, innovation, policy and other improvements. However, realizing these gains will require an exceptional level of collaboration among stakeholders in the agricultural value chain, including governments, companies, multilateral 
and civil-society organizations, farmers, scientists, consumers and entrepreneurs. There is a lot of research is being conducted all over the world in various areas of agriculture to overcome the food security problem and to evolve sustainable agricultural systems.

Scientometrics is a discipline which analyses scientific publications and citations appended to the papers to gain an understanding of the structure of science, growth of science at the global level, performance of a country in a particular domain, performance of institutions and scientific eminence of an individual scientist. It also helps in knowing the information seeking behavior of scientists and engineers by way of identifying where they publish and what they cite.

Balasubramanian and Ravanan ${ }^{[1]}$ have studied the global agriculture literature and highlighted the scientific output during 1945-2010 and focused on the growth of literature, highly productive countries and most preferred journals. A few scientometric studies in various countries in agricultural science have been carried out. ${ }^{[2-8]}$

Many scientometric studies have appeared in the literature to focus on the performance of nuclear science and technology. ${ }^{[9-23]}$ Scientometric studies are useful in understanding the growth of literature, identifying strengths and weaknesses of a country, organization and an individual in various domains of scientific endeavors. These studies will help the policy makers and science administrators to have better insights in framing science policy and guiding the researchers.

\section{Objectives}

The main objective of this study is to analyze the global research performance in the field of agricultural science as reflected in the publication and citation output during 1993-2012. In particular, the study focuses on the following aspects:

- To study the year-wise growth of publications and citations

- To study the continent-wise distribution of publications and citations

- To study the share of publications of highly productive countries

- To study the publication efficiency index (PEI) of highly productive countries

- To study the average citations per publication (ACP) of highly productive countries

- To study the distribution of publications and citations in various agricultural science sub-domains
- To study the specialization index (SI) of various countries in different agricultural sub-domains

- To study the variation of average impact factor (AIF) in agricultural science sub-domains

- To study the distribution of publications and citations of top ten countries in various agricultural science sub-domains

- To study the language-wise distribution of publications

- To study the highly cited publications in agricultural science

- To study the highly preferred journals for publication in the field, and

- To study the Quality of Research Output.

\section{MATERIALS AND METHODS}

Data were collected from Web of Science for the period 1993-2012. It is very difficult to define the scope of agricultural science using keywords and combination of keywords which may not always cover the entire gamut of literature on agricultural science and there is always every possibility of missing some percentage of literature. Therefore, it was decided to select all the journals on agricultural science and was identified from the subject categories provided by the Journal Citation Reports (JCR-2011). A list of 210 journals were identified falling within the scope of agricultural science as per JCR subject categories and all the bibliographic details of publications from these journals and citations to these publications were downloaded for the period 1993-2012. A total of 284,103 publications and 2,988,275 citations received to these publications were transferred to spread sheet application and analyzed the data as per objectives of the study. The bibliographic fields were analyzed by normal count procedure for continents, countries, sub-domain-wise, authorships and journals. Full credit was given to each continent, country regardless of whether it appears first or last in the author byline.

\section{RESULTS AND DISCUSSION}

\section{Year-wise Distribution of Publications and Citations}

A total of 284103 publications were published in Agricultural Science during 1993-2012 and these publications received 2,988,275 citations. Year-wise distribution of publications and citations is given in Figure 1 and Table 1. The highest number of publications 22,788 were published in 2011. The highest number of citations 205,098 were received 


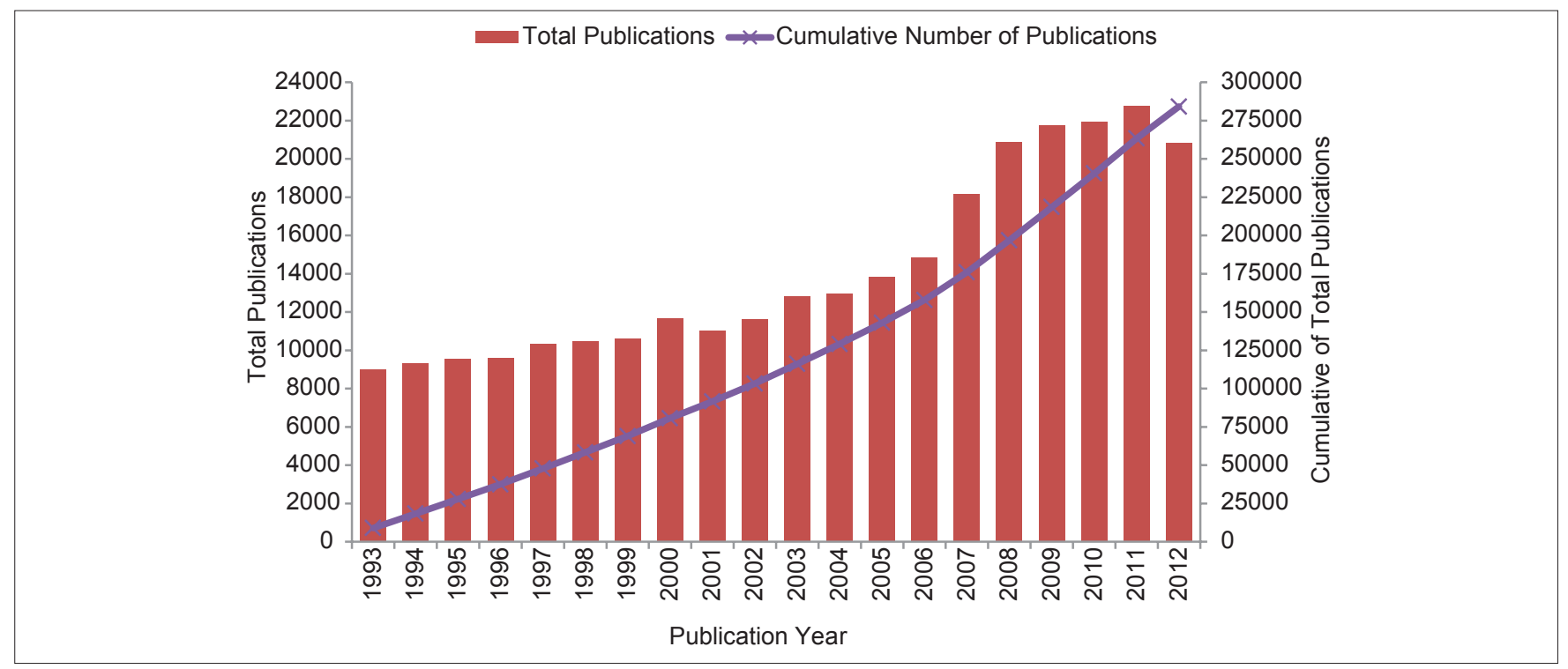

Figure 1: Year-wise distribution of publications in agricultural science (1993-2012)

Table 1: Year-wise distribution of publications and citations

\begin{tabular}{|c|c|c|c|c|c|c|c|c|}
\hline Year & TP & Percentage of TP & TC & Percentage of TC & ACP & TIF & AIF & CR \\
\hline 1993 & 8990 & 3.16 & 142914 & 4.78 & 15.90 & 15304.00 & 1.70 & 0.85 \\
\hline 1994 & 9332 & 3.28 & 141968 & 4.75 & 15.21 & 15717.91 & 1.68 & 0.85 \\
\hline 1995 & 9536 & 3.36 & 159036 & 5.32 & 16.68 & 16143.36 & 1.69 & 0.87 \\
\hline 1996 & 9608 & 3.38 & 164957 & 5.52 & 17.17 & 16466.02 & 1.71 & 0.87 \\
\hline 1997 & 10361 & 3.65 & 176383 & 5.90 & 17.02 & 17504.24 & 1.69 & 0.88 \\
\hline 1998 & 10500 & 3.70 & 176591 & 5.91 & 16.82 & 17673.89 & 1.68 & 0.89 \\
\hline 1999 & 10619 & 3.74 & 184386 & 6.17 & 17.36 & 17658.72 & 1.66 & 0.89 \\
\hline 2000 & 11687 & 4.11 & 205661 & 6.88 & 17.60 & 19331.93 & 1.65 & 0.90 \\
\hline 2001 & 11018 & 3.88 & 188281 & 6.30 & 17.09 & 18310.46 & 1.66 & 0.91 \\
\hline 2002 & 11635 & 4.10 & 205098 & 6.86 & 17.63 & 20110.76 & 1.73 & 0.92 \\
\hline 2003 & 12829 & 4.52 & 203891 & 6.82 & 15.89 & 21737.72 & 1.69 & 0.93 \\
\hline 2004 & 12984 & 4.57 & 182311 & 6.10 & 14.04 & 21791.79 & 1.68 & 0.92 \\
\hline 2005 & 13847 & 4.87 & 175798 & 5.88 & 12.70 & 23283.07 & 1.68 & 0.93 \\
\hline 2006 & 14862 & 5.23 & 163867 & 5.48 & 11.03 & 24828.33 & 1.67 & 0.93 \\
\hline 2007 & 18147 & 6.39 & 152562 & 5.11 & 8.41 & 27821.93 & 1.53 & 0.93 \\
\hline 2008 & 20861 & 7.34 & 140876 & 4.71 & 6.75 & 32977.85 & 1.58 & 0.94 \\
\hline 2009 & 21740 & 7.65 & 107703 & 3.60 & 4.95 & 33623.55 & 1.55 & 0.94 \\
\hline 2010 & 21937 & 7.72 & 74343 & 2.49 & 3.39 & 36734.85 & 1.67 & 0.95 \\
\hline 2011 & 22788 & 8.02 & 35486 & 1.19 & 1.56 & 39110.08 & 1.72 & 0.95 \\
\hline 2012 & 20822 & 7.33 & 6163 & 0.21 & 0.30 & 36909.87 & 1.77 & 0.96 \\
\hline Total & 284103 & 100.00 & 2988275 & 100.00 & 10.52 & 473040.33 & 1.67 & 0.92 \\
\hline
\end{tabular}

$\mathrm{TP}=$ Total publications, $\mathrm{TC}=$ Total citations, $\mathrm{ACP}=$ Average citations per publication, $\mathrm{TIF}=$ Total impact factor, AIF=Average impact factor per publication, $\mathrm{CR}=$ Collaboration rate

in 2002. The highest ACP 17.63 was in 2002. There were $63,623(22.39 \%)$ publications with no citations during the period under study. The highest total impact factor $(39,110.08)$ was in 2011 . The highest AIF 1.77 was in 2012. Overall collaboration rate was very high (0.92) as 261,525 publications of the total documents were multi-authored and the highest CR (0.96) was in 2012. An average $6.55 \%$ annual growth of publications was observed. An exponential growth of publications was observed except in 2012 which may be attributed to the input time-lag in the database.

\section{Continent-wise Distribution of Publications and Citations}

The number and growth of Agricultural Science literature 
in six continents of the world during 1993-2012 is illustrated in Table 2. It was observed that Europe is the most productive continent with 114,504 publications and 1,476,455 citations followed by North America with 89,881 publications and 1,241,421 citations and Asia with 83,454 publications and 610,791 citations.

Table 2: Continents-wise distribution of publications and citations in agricultural science (1993-2012)

\begin{tabular}{|c|c|c|c|c|c|c|c|c|c|}
\hline Rank & Continents & Total countries & TP & Percentage of TP & TC & Percentage of TC & $\mathrm{ACP}$ & AIF & Publication trend \\
\hline 1 & Europe & 47 & 114504 & 40.30 & 1476455 & 49.41 & 12.89 & 1.86 & \\
\hline 2 & North America & 16 & 89881 & 31.64 & 1241421 & 41.54 & 13.81 & 1.85 & \\
\hline 3 & Asia & 45 & 83454 & 29.37 & 610791 & 20.44 & 7.32 & 1.56 & \\
\hline 4 & South America & 12 & 22883 & 8.05 & 126361 & 4.23 & 5.52 & 1.16 & \\
\hline & & & & & & & & & \\
\hline 5 & Australia/Oceania & 7 & 15324 & 5.39 & 191361 & 6.40 & 12.49 & 1.79 & \\
\hline 6 & Africa & 45 & 12442 & 4.38 & 92716 & 3.10 & 7.45 & 1.57 & \\
\hline 7 & Without Affiliation & - & 2504 & 0.88 & 4253 & 0.14 & 1.70 & 0.76 & \\
\hline
\end{tabular}

$\mathrm{TP}=$ Total publications, $\mathrm{TC}=$ Total citations, $\mathrm{ACP}=$ Average citations per publication, $\mathrm{AIF}=$ Average impact factor per publication

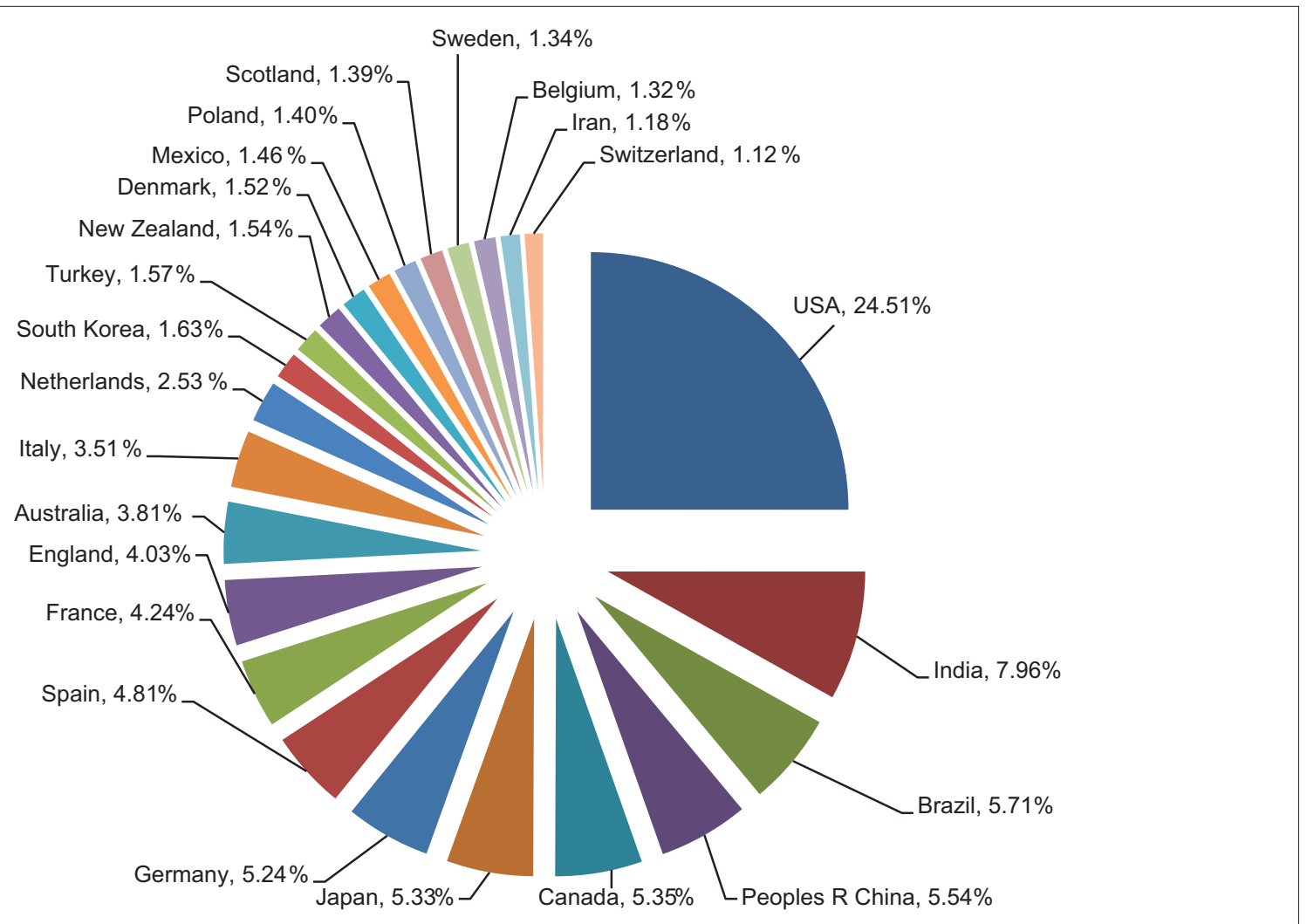

Figure 2: Countries share of publications in agricultural science ( $\geq 3000$ publications) 
Publications from North America received the highest average number of citations (13.81) per publication followed by Europe with 12.89 ACP, Australia/Oceania with 12.49 ACP, Africa with 7.45 and Asia with 7.32 ACP.

Germany is the highly productive country in Europe with 14,882 publications, 164,951 citations and 11.08 ACP. USA is the highly productive country in North America with 69,636 publications, 1,005,304 citations and 14.44 ACP India is the highly productive country in Asia with 22,615 publications, 98,954 citations and 4.38 ACP Brazil is the highly productive country in South America with 16,221 publications, 66,638 citations and 4.11 ACP. Australia is the highly productive country in Australia/Oceania with 10,814 publications, 135,635 citations and 12.54 ACP. South Africa is the highly productive country in Africa with 2404 publications, 17,139 citations and 7.13 ACP [Table 3].

\section{Share of Publications of Highly Productive Countries}

In all, there were 172 countries involved in research in agricultural science which published at least one publication. The publication share of highly productive countries ( $\geq 3000$ publications) in agricultural science varies from $1.12 \%$ to $24.51 \%$ during $1993-2012$ [Figure 2]. USA topped the list with highest share $(24.51 \%)$ of publications. India ranked second with $7.96 \%$ share of publications followed by Brazil with 5.71\%, Peoples R China with $5.54 \%$, Canada with 5.35\%, Japan with 5.33\%, Germany with $5.24 \%$, Spain with $4.81 \%$, France with $4.24 \%$ and England with $4.03 \%$ share of publications. Table 4 provides distribution of publications and citations of highly productive countries with $\geq 3000$ publications.

\section{Publication Efficiency Index}

PEI was used by Guan and $\mathrm{Ma}^{[24]}$ in their studies as a

Table 3: Highly productive countries in six continents (1993-2012)

\begin{tabular}{|c|c|c|c|c|c|c|c|c|}
\hline Continent & Rank & Country & TP & Percentage of TP & TC & Percentage of TC & ACP & $\overline{h \text {-index }}$ \\
\hline \multirow[t]{5}{*}{ Europe } & 1 & Germany & 14882 & 5.24 & 164951 & 5.52 & 11.08 & 105 \\
\hline & 2 & Spain & 13663 & 4.81 & 176754 & 5.91 & 12.94 & 104 \\
\hline & 3 & France & 12043 & 4.24 & 182169 & 6.10 & 15.13 & 109 \\
\hline & 4 & England & 11451 & 4.03 & 186493 & 6.24 & 16.29 & 119 \\
\hline & 5 & Italy & 9965 & 3.51 & 115833 & 3.88 & 11.62 & 95 \\
\hline \multirow[t]{5}{*}{ North America } & 1 & USA & 69636 & 24.51 & 1005304 & 33.64 & 14.44 & 201 \\
\hline & 2 & Canada & 15206 & 5.35 & 192526 & 6.44 & 12.66 & 107 \\
\hline & 3 & Mexico & 4150 & 1.46 & 36061 & 1.21 & 8.69 & 61 \\
\hline & 4 & Costa Rica & 291 & 0.10 & 2808 & 0.09 & 9.65 & 24 \\
\hline & 5 & Cuba & 270 & 0.10 & 1863 & 0.06 & 6.90 & 22 \\
\hline \multirow[t]{5}{*}{ Asia } & 1 & India & 22615 & 7.96 & 98954 & 3.31 & 4.38 & 83 \\
\hline & 2 & Peoples R China & 15751 & 5.54 & 117594 & 3.94 & 7.47 & 82 \\
\hline & 3 & Japan & 15150 & 5.33 & 137415 & 4.60 & 9.07 & 92 \\
\hline & 4 & South Korea & 4619 & 1.63 & 36315 & 1.22 & 7.86 & 60 \\
\hline & 5 & Turkey & 4462 & 1.57 & 31226 & 1.04 & 7.00 & 63 \\
\hline \multirow[t]{5}{*}{ South America } & 1 & Brazil & 16221 & 5.71 & 66638 & 2.23 & 4.11 & 64 \\
\hline & 2 & Argentina & 2922 & 1.03 & 28949 & 0.97 & 9.91 & 57 \\
\hline & 3 & Colombia & 1195 & 0.42 & 11611 & 0.39 & 9.72 & 48 \\
\hline & 4 & Chile & 1107 & 0.39 & 7680 & 0.26 & 6.94 & 36 \\
\hline & 5 & Venezuela & 450 & 0.16 & 2936 & 0.10 & 6.52 & 25 \\
\hline \multirow[t]{5}{*}{ Australia/Oceania } & 1 & Australia & 10814 & 3.81 & 135635 & 4.54 & 12.54 & 106 \\
\hline & 2 & New Zealand & 4383 & 1.54 & 54889 & 1.84 & 12.52 & 77 \\
\hline & 3 & Papua N Guinea & 49 & 0.02 & 271 & 0.01 & 5.53 & 9 \\
\hline & 4 & Fiji & 47 & 0.02 & 275 & 0.01 & 5.85 & 9 \\
\hline & 5 & Vanuatu & 27 & 0.01 & 256 & 0.01 & 9.48 & 10 \\
\hline \multirow[t]{5}{*}{ AFRICA } & 1 & South Africa & 2404 & 0.85 & 17139 & 0.57 & 7.13 & 42 \\
\hline & 2 & Nigeria & 1972 & 0.69 & 11225 & 0.38 & 5.69 & 37 \\
\hline & 3 & Kenya & 1235 & 0.43 & 13299 & 0.45 & 10.77 & 45 \\
\hline & 4 & Egypt & 1223 & 0.43 & 7766 & 0.26 & 6.35 & 33 \\
\hline & 5 & Ethiopia & 788 & 0.28 & 5064 & 0.17 & 6.43 & 27 \\
\hline
\end{tabular}

$\mathrm{TP}=$ Total publications, $\mathrm{TC}=$ Total citations, $\mathrm{ACP}=$ Average citations per publication 
Table 4: Trends of publications of highly productive countries in agricultural science (1993-2012)

\begin{tabular}{|c|c|c|c|c|c|c|c|}
\hline Country & TP & Percentage of TP & TC & Percentage of TC & AlF & ACP & Publication trend \\
\hline USA & 69636 & 24.51 & 1005304 & 33.64 & 1.91 & 14.44 & \\
\hline India & 22615 & 7.96 & 98954 & 3.31 & 0.96 & 4.38 & \\
\hline Brazil & 16221 & 5.71 & 66638 & 2.23 & 0.99 & 4.11 & \\
\hline Peoples R China & 15751 & 5.54 & 117594 & 3.94 & 2.18 & 7.47 & \\
\hline Canada & 15206 & 5.35 & 192526 & 6.44 & 1.71 & 12.66 & \\
\hline Japan & 15150 & 5.33 & 137415 & 4.60 & 1.62 & 9.07 & \\
\hline Germany & 14882 & 5.24 & 164951 & 5.52 & 1.65 & 11.08 & \\
\hline Spain & 13663 & 4.81 & 176754 & 5.91 & 2.10 & 12.94 & \\
\hline France & 12043 & 4.24 & 182169 & 6.10 & 2.06 & 15.13 & \\
\hline England & 11451 & 4.03 & 186493 & 6.24 & 2.01 & 16.29 & \\
\hline Australia & 10814 & 3.81 & 135635 & 4.54 & 1.85 & 12.54 & \\
\hline Italy & 9965 & 3.51 & 115833 & 3.88 & 1.81 & 11.62 & \\
\hline Netherlands & 7194 & 2.53 & 118872 & 3.98 & 2.05 & 16.52 & \\
\hline South Korea & 4619 & 1.63 & 36315 & 1.22 & 1.75 & 7.86 & \\
\hline Turkey & 4462 & 1.57 & 31226 & 1.04 & 1.32 & 7.00 & \\
\hline
\end{tabular}


Table 4: Contd...

\begin{tabular}{|c|c|c|c|c|c|c|c|}
\hline Country & TP & Percentage of TP & TC & Percentage of TC & AIF & ACP & Publication trend \\
\hline New Zealand & 4383 & 1.54 & 54889 & 1.84 & 1.64 & 12.52 & \\
\hline Denmark & 4313 & 1.52 & 61606 & 2.06 & 1.98 & 14.28 & \\
\hline Mexico & 4150 & 1.46 & 36061 & 1.21 & 1.53 & 8.69 & \\
\hline Poland & 3967 & 1.40 & 23847 & 0.80 & 1.28 & 6.01 & \\
\hline Scotland & 3961 & 1.39 & 67594 & 2.26 & 1.94 & 17.06 & \\
\hline Sweden & 3799 & 1.34 & 56194 & 1.88 & 2.08 & 14.79 & \\
\hline Belgium & 3744 & 1.32 & 49703 & 1.66 & 1.95 & 13.28 & \\
\hline Iran & 3351 & 1.18 & 10913 & 0.37 & 1.14 & 3.26 & \\
\hline Switzerland & 3191 & 1.12 & 42674 & 1.43 & 1.75 & 13.37 & \\
\hline
\end{tabular}

$\mathrm{TP}=$ Total publications, $\mathrm{TC}=$ Total citations, $\mathrm{AIF}=$ Average impact factor per publication, $\mathrm{ACP}=$ Average citations per publication

measure of research quality. It indicates whether the impact of publications in a country in a research field is compatible with the research efforts. The value of PEI $\geq 1$ for a country indicates that the impact of publications is more than the research effort devoted to it for that particular country and vice versa. The PEI for top 30 countries is shown in Figure 3.

The PEI indicates that in general the impact of research in Asian countries (region) is very weak despite their devoted research efforts as compared to, USA (1.37), Canada (1.20), Germany (1.05), Spain (1.23), France (1.44), England (1.55), Australia (1.19), Italy (1.11), Netherlands (1.57), New Zealand (1.19), Denmark (1.36), Scotland (1.62), Sweden (1.41), Belgium (1.26), Switzerland (1.27), Taiwan (1.07), Israel (1.62) and Finland (1.51), while Taiwan (1.07) is an exception. In other words, the Asian publications have not received enough citations in comparison to their large number of publications. Therefore, it is suggested that the Asian countries have to make efforts to publish their publications in high IF journals. In addition, the major countries in Asia like Peoples Republic of China, Japan, South Korea and Taiwan publish in Chinese, Japanese, Korean and Taiwanese are not easily understood by the scientific community in the rest of the world.

\section{Distribution of Countries According to Average Citations per Publication of Highly Productive Countries}

The ACP is one of the important indicators to know the quality of publications. Distribution of the top 30 countries according to ACP is given in Figure 4. Israel had the highest ACP (17.09) per publication followed by Scotland with 


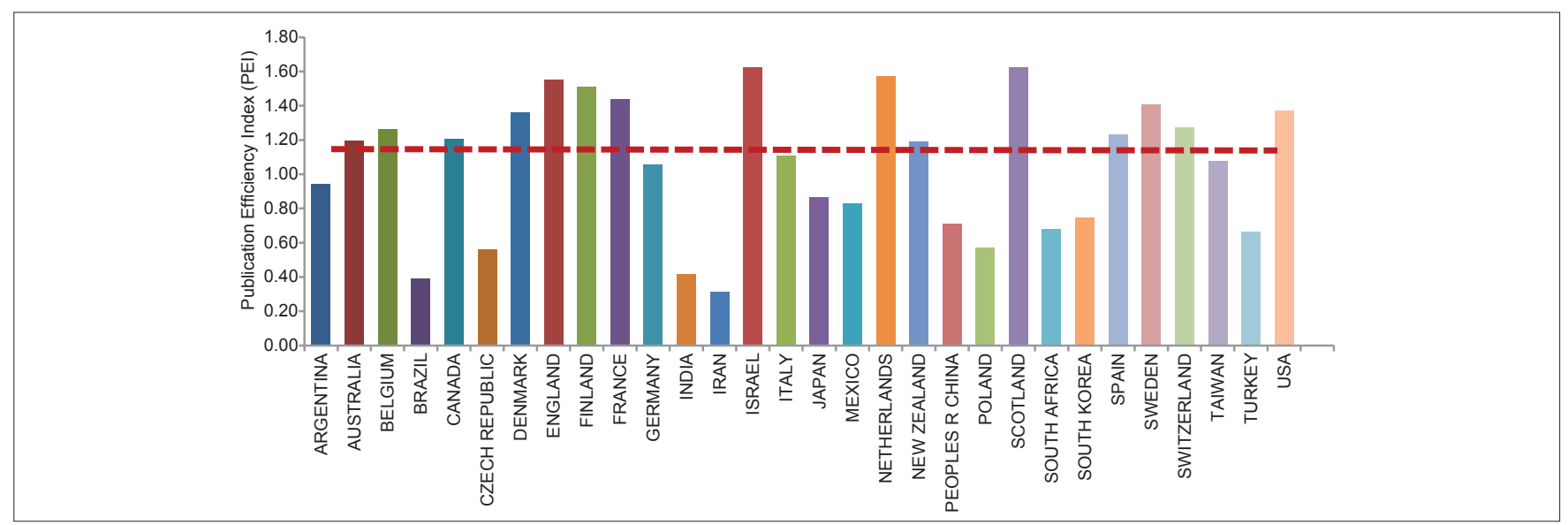

Figure 3: Publication efficiency index of highly productive countries in agricultural science

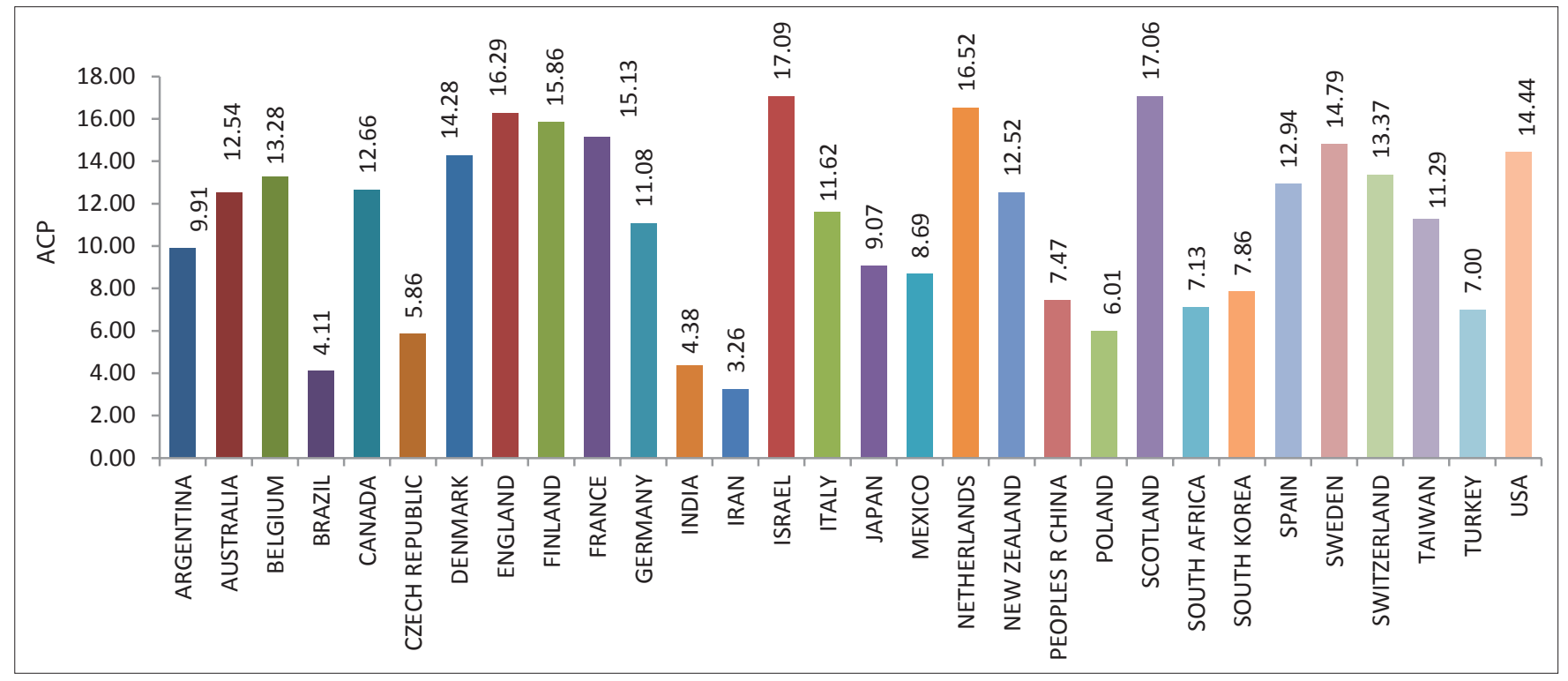

Figure 4: Average citations per publication of highly productive countries in agricultural science

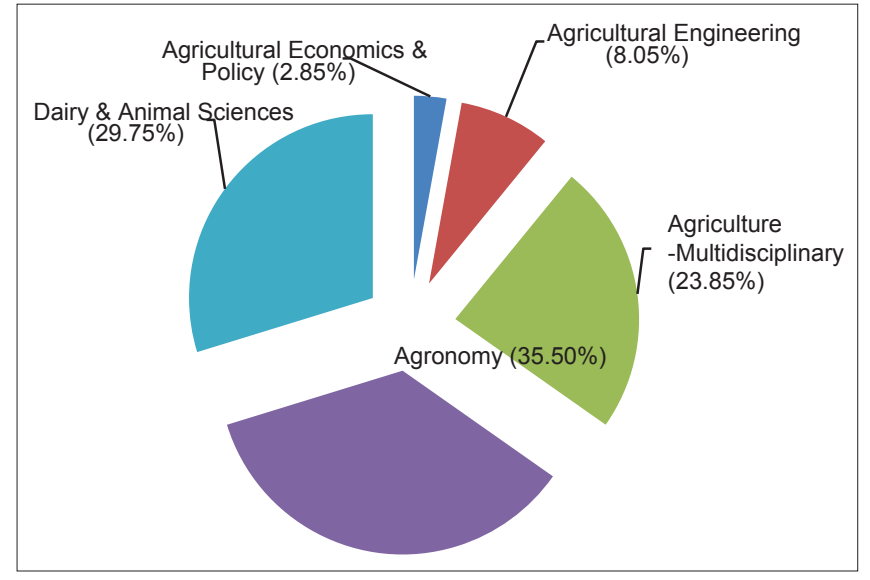

Figure 5: Distribution of publications in agricultural science sub-domains (1993-2012)

17.06 ACP, Netherlands with 16.52 ACP, England with 16.29 ACP, Finland with 15.86 ACP, France with 15.13 ACP,
Sweden with 14.79 ACP, USA with 14.44 ACP, Denmark with 14.28 ACP, Switzerland with 13.37 ACP, Belgium with 13.28 ACP, Spain with 12.94 ACP, Canada with 12.66 ACP and Australia with 12.54 citations per publication.

\section{Distribution of Publications and Citations in Agricultural Science Sub-Domains}

Based on the classification of subject-categories in JCR of Thomson Reuters, the publication output data of agricultural science research was classified into five sub-domains [Figure 5] during 1993-2012. Agronomy accounts for the largest share 100,845 of publications in the total worldwide output in agricultural science which received 1,109,679 citations followed by Dairy and Animal Sciences with 84,533 publications and 805,854 citations, Agriculture-Multidisciplinary with 67,760 publications J Scientometric Res. | Sep-Dec 2013 | Vol 2 | Issue 3 
and 743,078 citations, Agricultural Engineering with 22,870 publications and 271,427 citations and Agricultural Economics and Policy with 8095 publications and 58,237 citations [Table 5].

\section{Specialization Index}

Specialization index is the relationship between a country's share of global publications for a field of research and its world share of publications in all disciplines. If they are higher than 1 that indicates subjects in which research is especially active, and thus supported as priorities by the research policy decision-makers. Conversely, an index of $<1$ indicates the research areas which are not given emphasis. ${ }^{[25]}$

\section{Agricultural Economics and Policy}

For the period of 1993-2012, USA obtained the highest SI of 2.19 in the area of Agricultural Economics and Policy followed by Kenya with 1.85, South Africa with 1.75, England with 1.72, Australia with 1.63, Canada with 1.53, Norway with 1.53, Germany with 1.48 and Netherlands with 1.17 [Figure 6].

Table 5: Distribution of publications and citations in agricultural science sub-domains

\begin{tabular}{|c|c|c|c|c|c|c|}
\hline Sub-domains & TP & Percentage of TP & TC & Percentage of TC & ACP & Publication trend \\
\hline Agronomy & 100845 & 35.50 & 1109679 & 37.13 & 11.00 & \\
\hline Dairy and animal sciences & 84533 & 29.75 & 805854 & 26.97 & 9.53 & \\
\hline Agriculture-multidisciplinary & 67760 & 23.85 & 743078 & 24.87 & 10.97 & \\
\hline Agricultural engineering & 22870 & 8.05 & 271427 & 9.08 & 11.87 & \\
\hline Agricultural economics and policy & 8095 & 2.85 & 58237 & 1.95 & 7.19 & \\
\hline Total & 284103 & 100.00 & 2988275 & 100.00 & 10.52 & \\
\hline
\end{tabular}

$\mathrm{TP}=$ Total publications, $\mathrm{TC}=$ Total citations, $\mathrm{ACP}=$ Average citations per publication

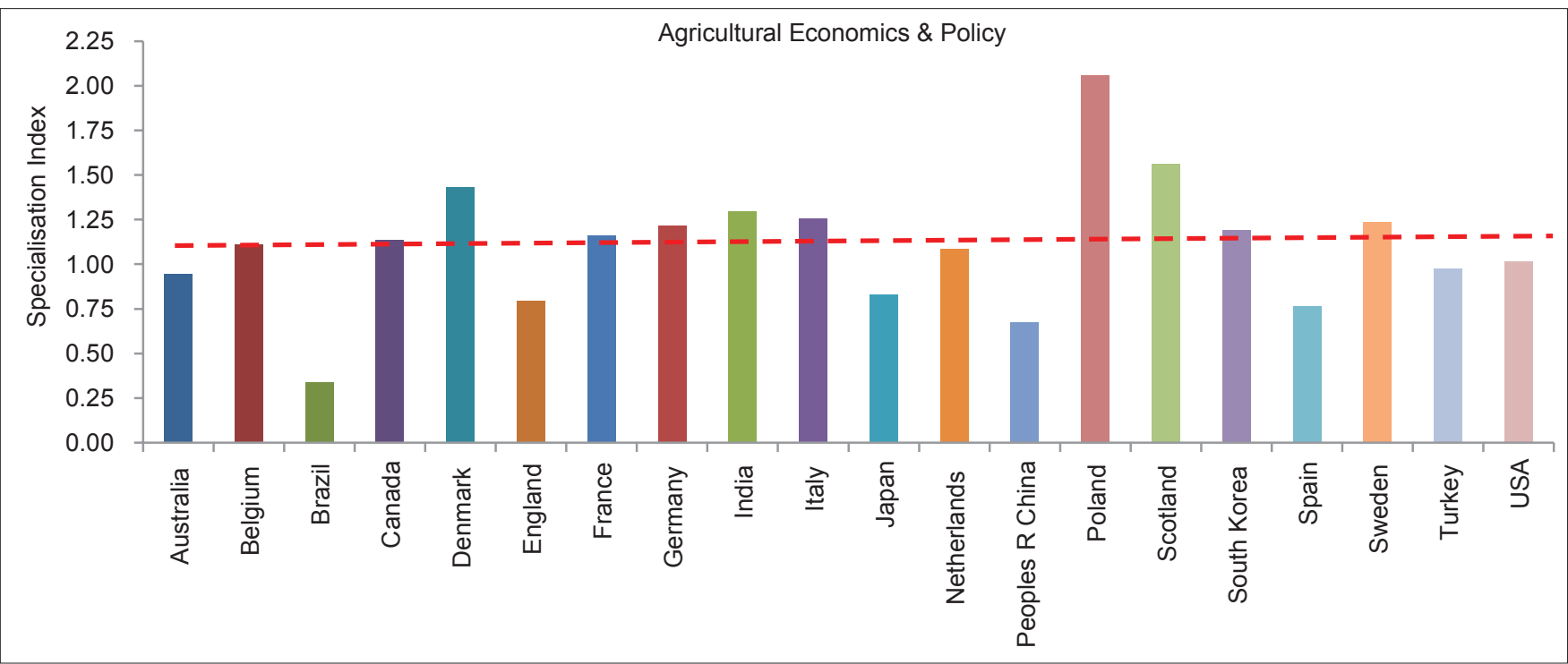

Figure 6: Specialization index for top 20 countries in agricultural economics and policy sub-domain (1993-2012) 


\section{Agricultural Engineering}

For the period of 1993-2012, South Korea obtained the highest SI of 3.22 in the area of Agricultural Engineering followed by Taiwan with 2.40, Peoples R China with 2.06, Greece with 1.72, Sweden with 1.71, Turkey with 1.52, India with 1.24, Spain with 1.19, USA with 1.09 and Belgium with 1.00 [Figure 7].

\section{Agriculture-Multidisciplinary}

For the period of 1993-2012, Brazil obtained the highest SI of 2.07 in the area of Agriculture-Multidisciplinary followed by Taiwan with 2.05, Switzerland with 1.54 , Spain with 1.53, New Zealand with 1.50, Japan with 1.20, England with 1.16, India with 1.14, Turkey with 1.08,
Peoples R China with 1.01, Italy with 1.00 and Mexico with 1.00 [Figure 8].

\section{Agronomy}

For the period of 1993-2012, Hungary obtained the highest SI of 1.93 in the area of Agronomy followed by Argentina with 1.29, Iran with 1.23, Mexico with 1.22, Australia with 1.21, Canada with 1.19, Japan with 1.14, USA with 1.11, France with 1.08, England with 1.08, Peoples R China with 1.07 and Netherlands with 1.00 [Figure 9].

\section{Dairy and Animal Sciences}

For the period of 1993-2012, Poland obtained the highest SI of 2.06 in the area of Dairy and Animal Sciences

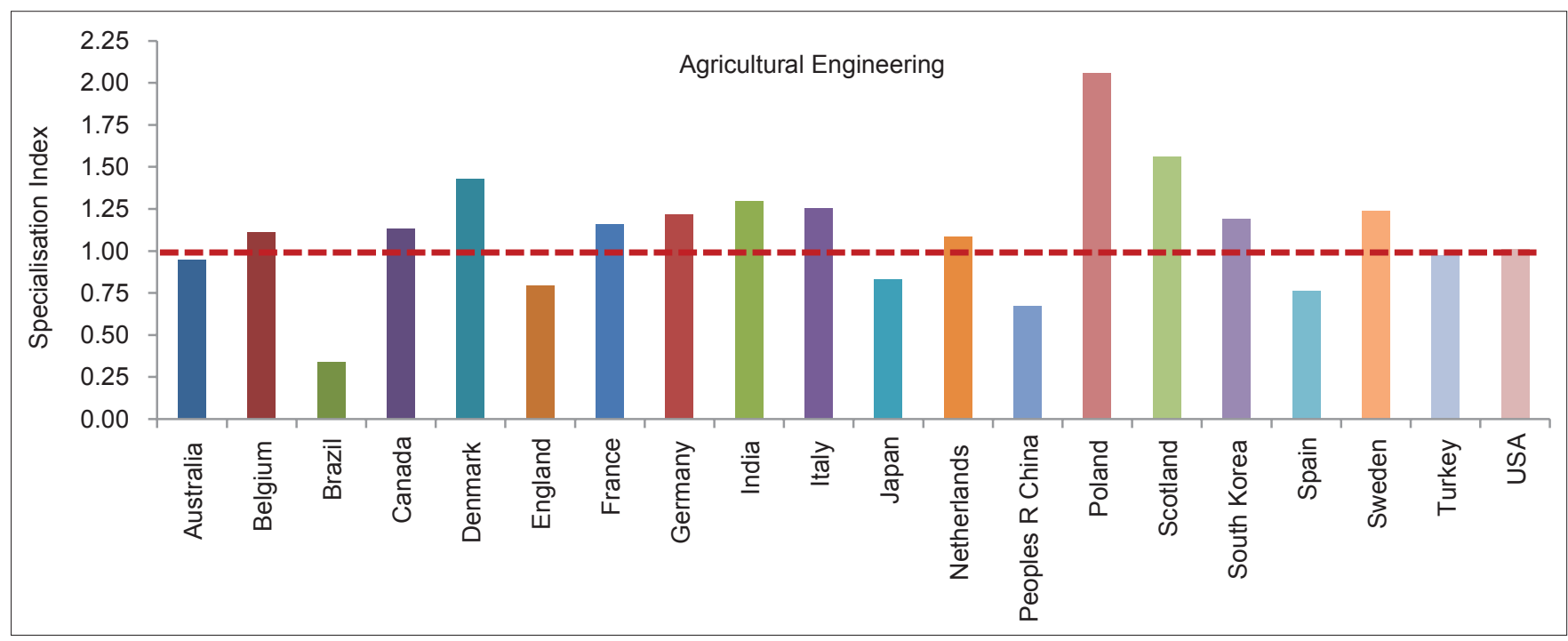

Figure 7: Specialization index for top 20 countries in agricultural engineering sub-domain (1993-2012)

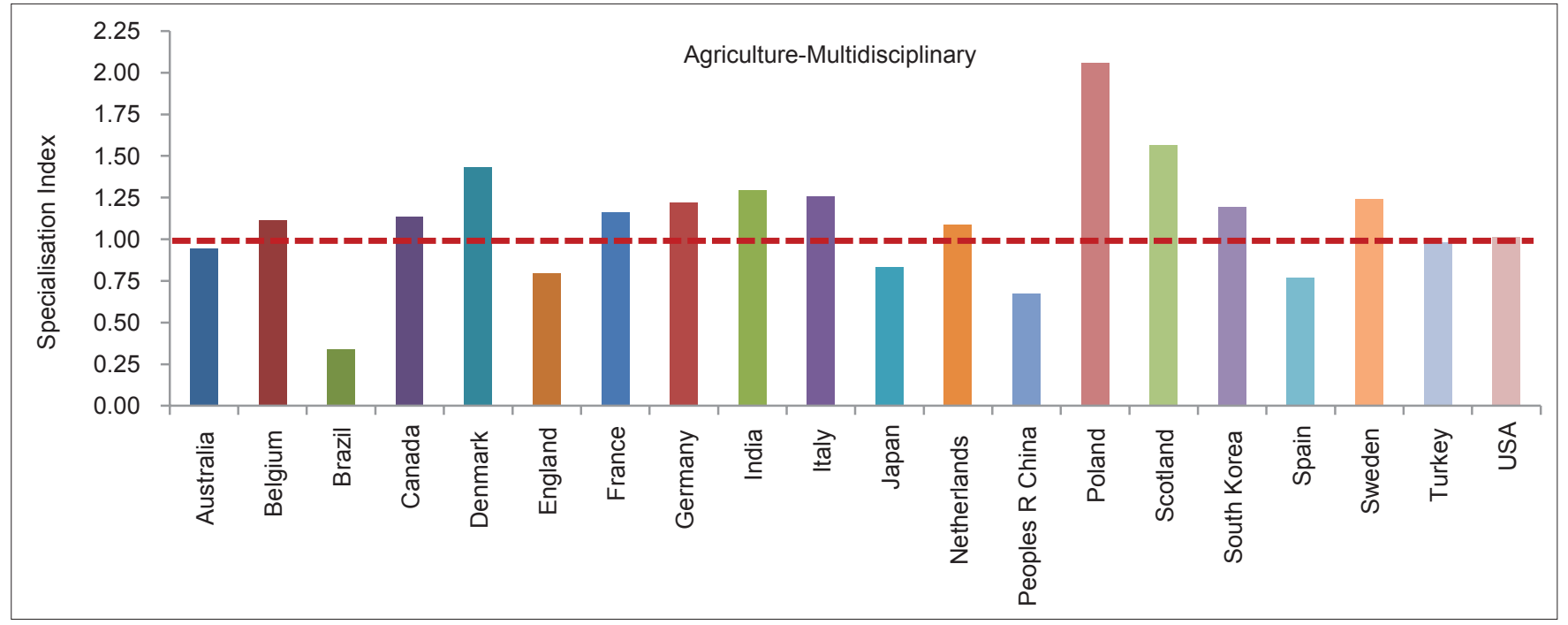

Figure 8: Specialization index for top 20 countries in agriculture-multidisciplinary sub-domain (1993-2012) 
followed by Scotland with 1.56, Denmark with 1.43, India with 1.29 , Italy with 1.26 , Sweden with 1.24 , Germany with 1.22, South Korea with 1.19, France with 1.16, Canada with 1.13 and Belgium with 1.11 [Figure 10].

\section{Variation of Average Impact Factor in Agricultural Science Sub-Domains}

Figure 11 gives the distribution of various agricultural science sub-domains according to AIF during the period under study. It is revealed from this analysis that there is a significant variation in AIF in various agricultural science sub-domains. There are many reasons for variation in IF in various sub-domains. ${ }^{[2]}$ The number of researchers working in a field is one of the important factors, the more number of active researchers in a field tend to receive more number of citations than the field with less number of active researchers. The highest AIF (3.16) is for agriculture engineering followed by Agriculture-Multidisciplinary (1.69) and Agronomy (1.61).

\section{Distribution of Publications and Citations of Top 10 Countries in Agricultural Science Sub-Domains}

Table 6 provides distribution of publications and citations of top 10 countries in various agricultural science domains. USA had the highest number of publications in all domains: Agricultural Economics and Policy (4342), Agricultural Engineering (6099), Agriculture-Multidisciplinary $(10,644)$, Agronomy $(27,540)$ and Dairy and Animal Sciences $(21,011)$.

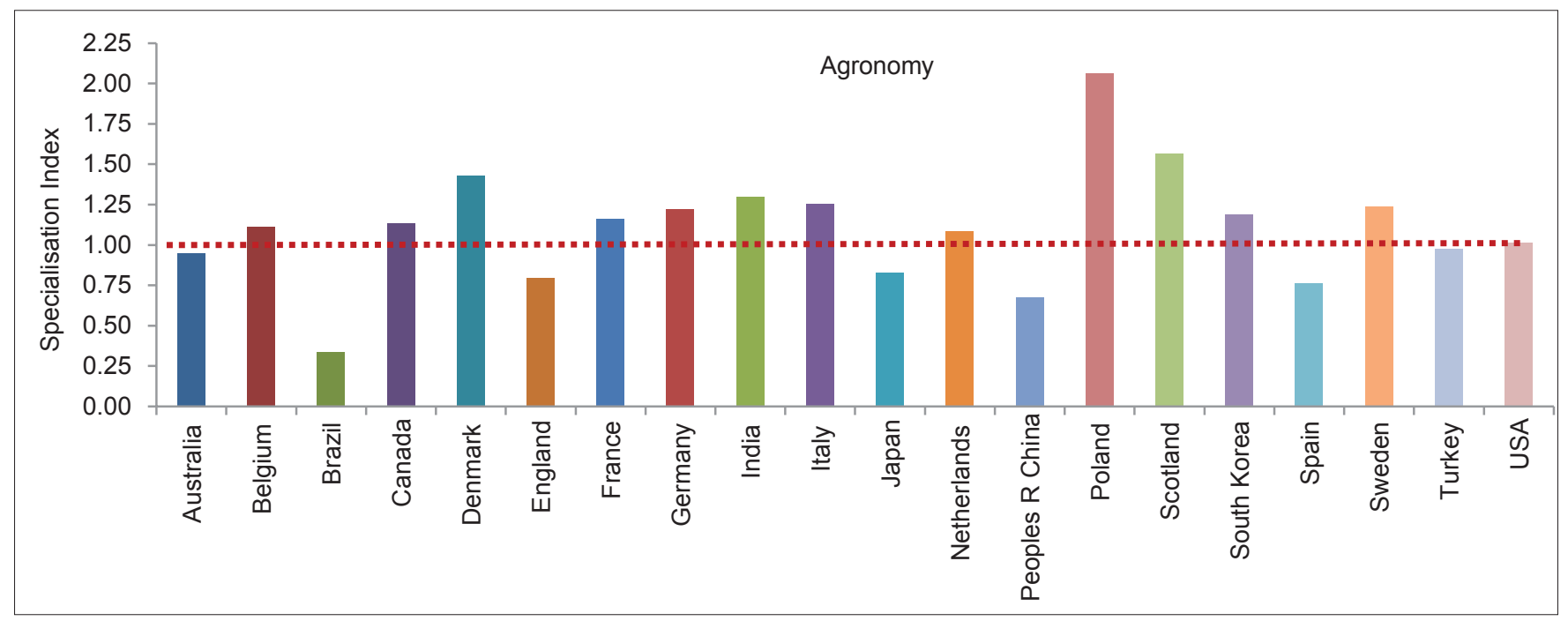

Figure 9: Specialization index for top 20 countries in Agronomy sub-domain (1993-2012)

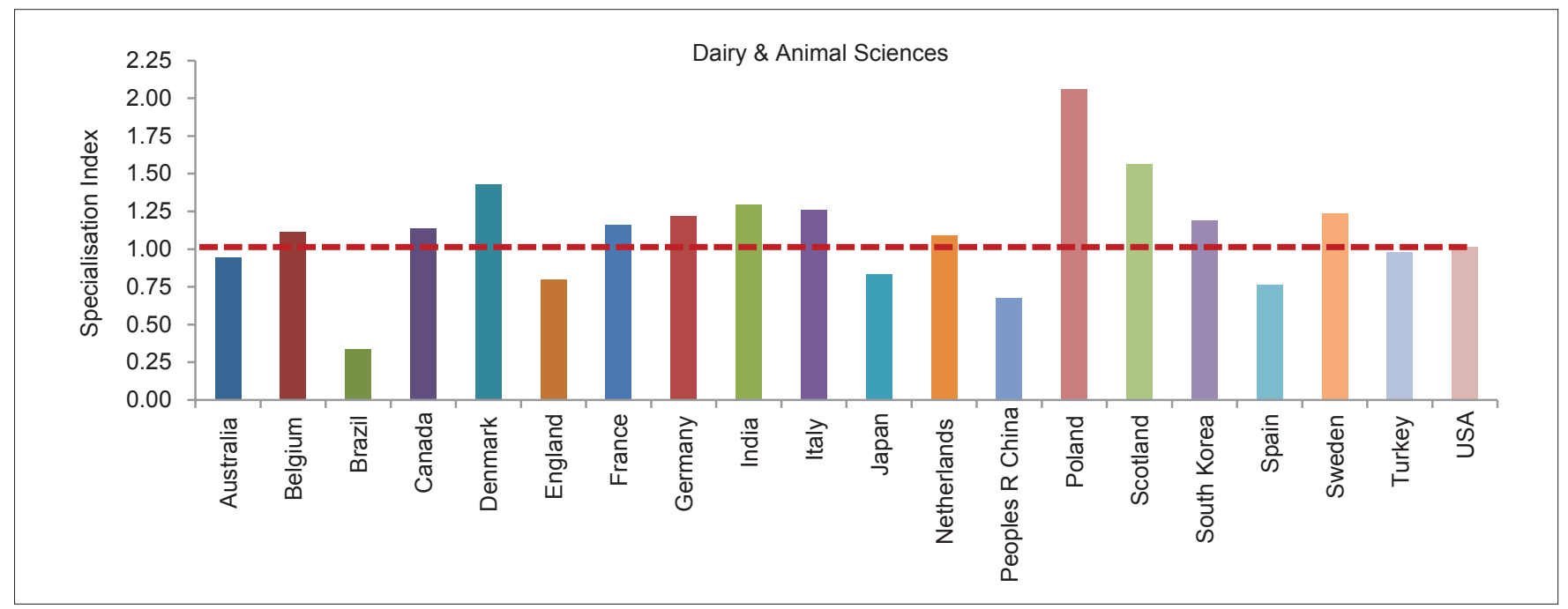

Figure 10: Specialization index for top 20 countries in dairy and animal sciences sub-domain (1993-2012) 
Table 6: Distribution of publications and citations of top 10 countries in various sub-domains

\begin{tabular}{|c|c|c|c|c|c|c|}
\hline Sub-domains & Rank & Country & TP & TC & ACP & AIF \\
\hline \multirow{10}{*}{$\begin{array}{l}\text { Agricultural } \\
\text { economics and } \\
\text { policy }\end{array}$} & 1 & USA & 4342 & 37160 & 8.56 & 1.11 \\
\hline & 2 & Canada & 664 & 4040 & 6.08 & 1.08 \\
\hline & 3 & Germany & 626 & 2327 & 3.72 & 0.78 \\
\hline & 4 & England & 560 & 5260 & 9.39 & 1.55 \\
\hline & 5 & Australia & 503 & 3730 & 7.42 & 1.16 \\
\hline & 6 & Spain & 375 & 952 & 2.54 & 0.67 \\
\hline & 7 & France & 244 & 1598 & 6.55 & 1.30 \\
\hline & 8 & Netherlands & 240 & 2282 & 9.51 & 1.33 \\
\hline & 9 & Peoples R China & 175 & 639 & 3.65 & 0.82 \\
\hline & 10 & Italy & 162 & 1136 & 7.01 & 1.44 \\
\hline \multirow{10}{*}{$\begin{array}{l}\text { Agricultural } \\
\text { engineering }\end{array}$} & 1 & USA & 6099 & 64855 & 10.63 & 2.29 \\
\hline & 2 & Peoples R China & 2611 & 21737 & 8.33 & 4.25 \\
\hline & 3 & India & 2254 & 30925 & 13.72 & 3.59 \\
\hline & 4 & Spain & 1305 & 19267 & 14.76 & 3.70 \\
\hline & 5 & South Korea & 1199 & 7385 & 6.16 & 2.27 \\
\hline & 6 & Canada & 990 & 14819 & 14.97 & 3.07 \\
\hline & 7 & Japan & 897 & 9428 & 10.51 & 3.20 \\
\hline & 8 & Brazil & 838 & 8194 & 9.78 & 2.77 \\
\hline & 9 & Italy & 674 & 7867 & 11.67 & 3.23 \\
\hline & 10 & France & 631 & 8579 & 13.60 & 3.56 \\
\hline \multirow{10}{*}{$\begin{array}{l}\text { Agriculture- } \\
\text { multidisciplinary }\end{array}$} & 1 & USA & 10644 & 185935 & 17.47 & 2.25 \\
\hline & 2 & Brazil & 8008 & 27364 & 3.42 & 0.84 \\
\hline & 3 & India & 6168 & 15912 & 2.58 & 0.57 \\
\hline & 4 & Spain & 4992 & 78225 & 15.67 & 2.20 \\
\hline & 5 & Japan & 4334 & 43515 & 10.04 & 1.55 \\
\hline & 6 & Peoples R China & 3800 & 26988 & 7.10 & 1.96 \\
\hline & 7 & Germany & 3202 & 40428 & 12.63 & 1.84 \\
\hline & 8 & England & 3169 & 54707 & 17.26 & 2.16 \\
\hline & 9 & France & 2406 & 44375 & 18.44 & 2.42 \\
\hline & 10 & Italy & 2380 & 41332 & 17.37 & 2.40 \\
\hline \multirow[t]{10}{*}{ Agronomy } & 1 & USA & 27540 & 391789 & 14.23 & 1.80 \\
\hline & 2 & Canada & 6407 & 71315 & 11.13 & 1.44 \\
\hline & 3 & Japan & 6131 & 58058 & 9.47 & 1.60 \\
\hline & 4 & Peoples R China & 6009 & 54282 & 9.03 & 1.93 \\
\hline & 5 & Brazil & 5706 & 21228 & 3.72 & 0.83 \\
\hline & 6 & India & 5430 & 38130 & 7.02 & 1.37 \\
\hline & 7 & Germany & 5224 & 79249 & 15.17 & 2.01 \\
\hline & 8 & Australia & 4642 & 73194 & 15.77 & 2.07 \\
\hline & 9 & France & 4607 & 77542 & 16.83 & 2.09 \\
\hline & 10 & England & 4382 & 74845 & 17.08 & 1.96 \\
\hline \multirow{10}{*}{$\begin{array}{l}\text { Dairy and } \\
\text { animal sciences }\end{array}$} & 1 & USA & 21011 & 325565 & 15.49 & 1.93 \\
\hline & 2 & India & 8713 & 13682 & 1.57 & 0.30 \\
\hline & 3 & Germany & 5396 & 37721 & 6.99 & 1.14 \\
\hline & 4 & Canada & 5130 & 68332 & 13.32 & 1.62 \\
\hline & 5 & France & 4155 & 50075 & 12.05 & 1.62 \\
\hline & 6 & Japan & 3743 & 26220 & 7.01 & 1.37 \\
\hline & 7 & Italy & 3724 & 21372 & 5.74 & 1.08 \\
\hline & 8 & Peoples R China & 3156 & 13948 & 4.42 & 1.26 \\
\hline & 9 & Spain & 3111 & 30394 & 9.77 & 1.67 \\
\hline & 10 & Australia & 3044 & 32804 & 10.78 & 1.35 \\
\hline
\end{tabular}

$\mathrm{TP}=$ Total publications, $\mathrm{TC}=$ Total citations, $\mathrm{ACP}=$ Average citations per publication, $\mathrm{AIF}=$ Average impact factor per publication

\section{Language-wise Distribution of Publications}

Publications on agricultural science are spread over 19 languages. The most predominant language used for communication was English. Language-wise distribution of publications on agricultural science is given in Figure 12.

\section{Distribution of Top Keywords}

Keywords are one of the best scientometric indicators to understand and grasp instantaneously the thought content of the papers and to find out the growth of the subject field. ${ }^{[2]}$ The high frequency keywords will enable us to understand what are the aspects of agricultural science have been studied. Figure 13 gives 5 years blocks-wise distribution of top keywords in agricultural science. Table 7 gives a list of high frequency keywords appeared more than 500 times.

\section{Highly Cited Publications}

The most highly cited 22 agricultural science publications (which have got at least 600 citations) during the period of study are listed in Table 8 . The number of citations does not necessarily indicate the quality of paper, but it is a measure of its impact in this field. The most frequently cited one was "Biodiesel production: A review" published in Bioresource Technol. 1999; 70:1-15 by Ma and Hanna with 1483 citations. Out of 22 highly cited publications 15 are journal articles and 7 are review articles.

\section{Journals Preferred for Publication by the Agricultural Scientists}

The scientific literature on agricultural science is spread over 210 different Web of Science source journals. More than $33 \%$ of the publications are published in only 11 key-journals. Table 9 gives the leading journals each with IF, number of publications, number of citations, and ACP. For scientists, such information could be valuable with respect to the selection of the appropriate journals for publishing their own results.

\section{Quality of Research Output}

Around $99.69 \%$ (283227) of the total publications were published in the journals with IF ranging from 0.001-5.20 and received $99.98 \%(2,987,671)$ citations, and around $0.31 \%$ (876) publications published in journals having zero IF. A significantly large number 


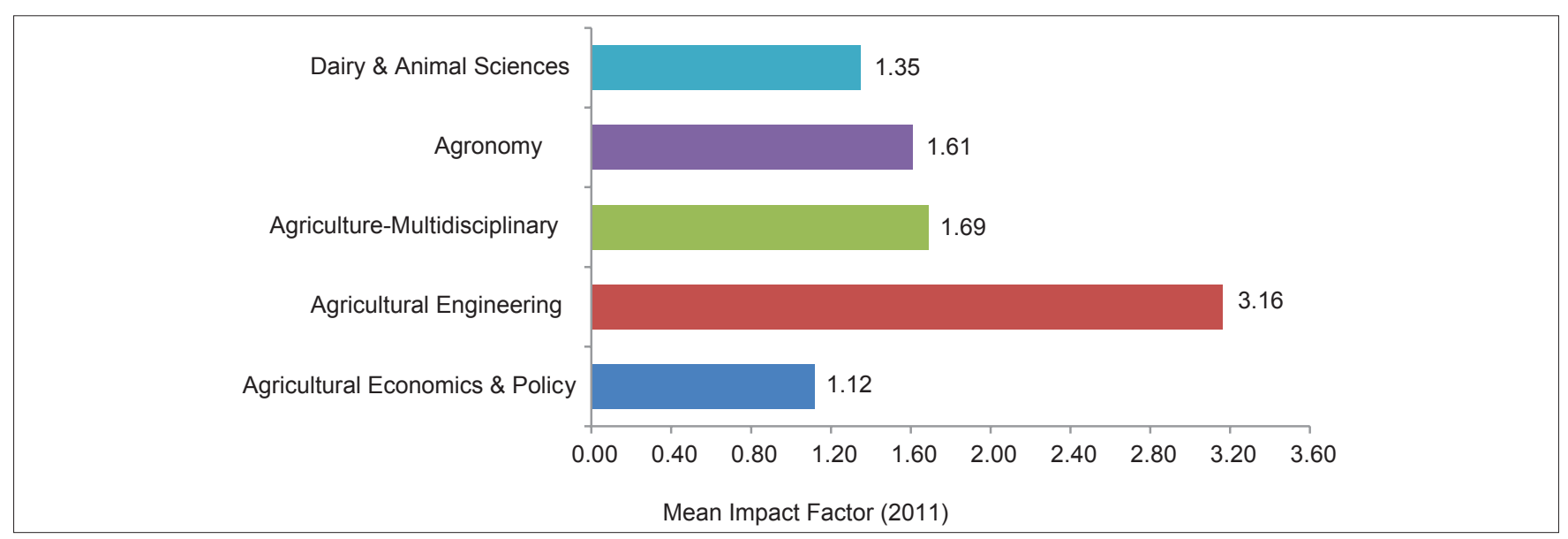

Figure 11: Variation of average impact factor in agricultural science sub-domains

\begin{tabular}{|c|c|c|c|}
\hline English (94.17\%) & $\left\{\begin{array}{l}\text { Other Languages } \\
(5.83 \%)\end{array}\right.$ & $\begin{array}{l}\text { - Czech } \\
\text { - Dutch } \\
\text {-English; Czech; Slovak } \\
\text { "English; Estonian } \\
\text {-English; German } \\
\text {-Estonian } \\
\text {-Finnish } \\
\text {-French } \\
\text { - German } \\
\text { - German; English } \\
\text { - Italian } \\
\text {-Japanese }\end{array}$ & $\begin{array}{l}\text { - Korean } \\
\text { "Lithuanian } \\
\text { - Polish } \\
\text { - Portuguese } \\
\text {-Portuguese; English } \\
\text { - Rumanian } \\
\text { - Russian } \\
\text {-Slovak } \\
\text { "Spanish } \\
\text { "Spanish; English } \\
\text {-Turkish } \\
\text {-Welsh }\end{array}$ \\
\hline
\end{tabular}

Figure 12: Language-wise distribution of publications in agricultural science

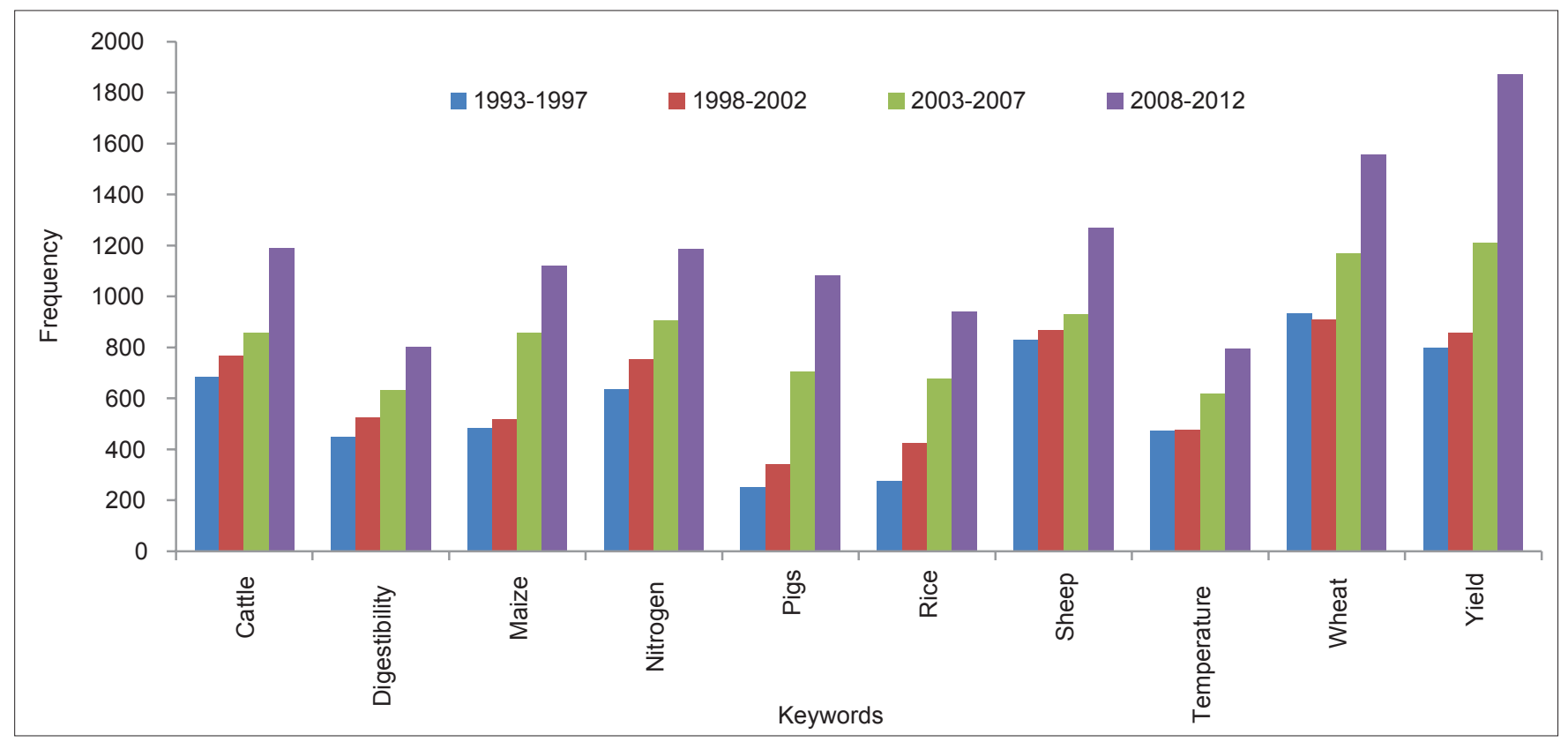

Figure 13: Five years block-wise distribution of top keywords in agricultural science (1993-2012)

of publications $32.62 \%$ (92663) appeared in journals having IF $1.00-<2.00$. Table 10 gives distribution of publications and citations according to IF range of the journal publications.

\section{CONCLUSION}

This study explores the characteristics of global agricultural science research during 1993-2012 based on the Web of 
Table 7: Distribution of high frequency keywords in agricultural science

\begin{tabular}{|c|c|c|c|c|c|}
\hline Keywords & Frequency & Keywords & Frequency & Keywords & Frequency \\
\hline Yield & 4735 & Molecular markers & 974 & Solanum tuberosum & 737 \\
\hline Wheat & 4566 & Poultry & 967 & Mastitis & 734 \\
\hline Sheep & 3893 & Calcium & 959 & Gene expression & 731 \\
\hline Cattle & 3496 & Rapd & 959 & Alfalfa & 725 \\
\hline Nitrogen & 3478 & Grain yield & 958 & Polymerase chain reaction & 721 \\
\hline Maize & 2974 & Biological control & 953 & Populations & 718 \\
\hline Pigs & 5145 & Inheritance & 953 & Tillage & 713 \\
\hline Digestibility & 2404 & Photosynthesis & 953 & Growth performance & 712 \\
\hline Temperature & 2356 & Amino acids & 951 & Rflp & 710 \\
\hline Rice & 2314 & Hplc & 948 & Antioxidants & 709 \\
\hline Quality & 2276 & Water & 921 & Efficiency & 708 \\
\hline Phosphorus & 2245 & Oryza sativa & 918 & Grazing & 695 \\
\hline Resistance & 2171 & Fertilization & 917 & Copper & 693 \\
\hline Protein & 2142 & Simulation & 905 & Lignin & 687 \\
\hline Soil & 2125 & Progesterone & 903 & Pasture & 683 \\
\hline Broiler & 2107 & Energy & 899 & Elisa & 681 \\
\hline Barley & 1955 & Dairy cows & 898 & Aflp & 678 \\
\hline Genetic diversity & 1783 & Plants & 889 & Expression & 677 \\
\hline Triticum aestivum & 1656 & Milk yield & 878 & Stability & 677 \\
\hline Biomass & 1594 & Productivity & 877 & Climate change & 676 \\
\hline Irrigation & 1584 & Drought & 876 & Adsorption & 673 \\
\hline Corn & 1569 & Buffalo & 875 & Phaseolus vulgaris & 672 \\
\hline Management & 1487 & Starch & 873 & Allelopathy & 671 \\
\hline Chicken & 1461 & Agriculture & 872 & Microsatellite & 671 \\
\hline Goat & 1424 & Diversity & 868 & Broilers & 668 \\
\hline Milk & 1402 & Breeding & 867 & Kinetics & 664 \\
\hline Heritability & 1391 & Environment & 857 & Economics & 656 \\
\hline Soybean & 1375 & Disease resistance & 850 & Ethanol & 653 \\
\hline Cultivars & 1354 & Antioxidant activity & 849 & Body weight & 651 \\
\hline Dairy cow & 1346 & Germplasm & 845 & Systems & 648 \\
\hline Germination & 1344 & Salinity & 843 & Cows & 644 \\
\hline Quantitative trait loci & 1341 & Behavior & 841 & Degradation & 644 \\
\hline Stress & 1331 & Lactation & 841 & Glucose & 644 \\
\hline Beef cattle & 1314 & Bovine & 837 & Potassium & 640 \\
\hline Nutrition & 1306 & Dairy cattle & 834 & Methane & 639 \\
\hline Model & 1270 & Glycine max & 833 & Swine & 639 \\
\hline Identification & 1223 & Evapotranspiration & 830 & Yield components & 638 \\
\hline Fertility & 1208 & Nitrate & 821 & Chemical composition & 633 \\
\hline Reproduction & 1196 & Rumen & 812 & Feed intake & 633 \\
\hline Storage & 1183 & Cotton & 805 & Fertilizer & 633 \\
\hline Zea mays & 1162 & Welfare & 805 & Biodiversity & 625 \\
\hline Meat quality & 1133 & Competition & 803 & Heat stress & 620 \\
\hline Fatty acids & 1132 & Milk production & 799 & Heterosis & 620 \\
\hline Metabolism & 1124 & Zinc & 799 & Toxicity & 618 \\
\hline Goats & 1058 & Polymorphism & 798 & DNA & 604 \\
\hline Potato & 1042 & Forage & 786 & Pregnancy & 604 \\
\hline Tomato & 1029 & Sorghum & 786 & Modeling & 602 \\
\hline Fermentation & 1001 & Beef & 767 & Intake & 598 \\
\hline $\mathrm{Ph}$ & 981 & Turkey & 767 & Tolerance & 595 \\
\hline Antioxidant & 974 & Digestion & 746 & Fat & 594 \\
\hline
\end{tabular}

$\mathrm{Ph}=$ Potential of hydrogen, $\mathrm{Hplc}=$ High performance liquid chromatography, Rflp= Restriction fragment length polymorphism, Aflp= Amplified fragment length polymorphism, DNA = Deoxyribonucleic acid 
Table 8: Highly cited publications in agricultural science ( $\geq 600$ citations)

\begin{tabular}{|c|c|c|c|c|c|}
\hline Bibliographic details & $\begin{array}{l}\text { IF } \\
2011\end{array}$ & $\begin{array}{l}\text { Times } \\
\text { cited }\end{array}$ & $\begin{array}{l}\text { Document } \\
\text { type }\end{array}$ & Sub-domains & $\begin{array}{l}\text { Country } \\
\text { collaboration }\end{array}$ \\
\hline Biodiesel production....by Ma et al., Bioresour Technol. 1999;70:1-15 & 4.98 & 1483 & Article & $\begin{array}{l}\text { Agricultural } \\
\text { engineering }\end{array}$ & USA \\
\hline $\begin{array}{l}\text { Statistical analysis of repeated... by Littell et al., J Anim Sci. } \\
\text { 1998;76:1216-231 }\end{array}$ & 2.10 & 1210 & Article & $\begin{array}{l}\text { Dairy and } \\
\text { animal sciences }\end{array}$ & USA \\
\hline $\begin{array}{l}\text { Features of promising technologies...by Mosier et al., Bioresour Technol. } \\
\text { 2005;96:673-86 }\end{array}$ & 4.98 & 1125 & Review & $\begin{array}{l}\text { Agricultural } \\
\text { engineering }\end{array}$ & USA \\
\hline $\begin{array}{l}\text { Hydrolysis of lignocellulosic materials... by Sun et al., Bioresour Technol. } \\
\text { 2002;83: 1-11 }\end{array}$ & 4.98 & 1083 & Review & $\begin{array}{l}\text { Agricultural } \\
\text { engineering }\end{array}$ & USA \\
\hline $\begin{array}{l}\text { The chemistry behind antioxidant... by Huang et al., J Agr Food Chem. } \\
\text { 2005;53:1841-856 }\end{array}$ & 2.82 & 1024 & Review & $\begin{array}{l}\text { Agriculture- } \\
\text { multidisciplinary }\end{array}$ & $\begin{array}{l}\text { Singapore/ } \\
\text { USA }\end{array}$ \\
\hline $\begin{array}{l}\text { Remediation of dyes in textile...by Robinson et al., Bioresour Technol. } \\
2001 ; 77: 247-255\end{array}$ & 4.98 & 1015 & Review & $\begin{array}{l}\text { Agricultural } \\
\text { engineering }\end{array}$ & England \\
\hline The comparison of RFLP, RAPD...by Powell et al., Mol Breed. 1996;2:225-38 & 2.85 & 957 & Article & Agronomy & USA/Italy \\
\hline $\begin{array}{l}\text { Antioxidant activity and total...by Velioglu et al., J Agr Food Chem. } \\
\text { 1998;46:4113-117 }\end{array}$ & 2.82 & 931 & Article & $\begin{array}{l}\text { Agriculture- } \\
\text { multidisciplinary }\end{array}$ & Canada \\
\hline $\begin{array}{l}\text { Antioxidant activity of plant...by Kahkonen et al., J Agr Food Chem. } \\
\text { 1999;47:3954-962 }\end{array}$ & 2.82 & 922 & Article & $\begin{array}{l}\text { Agriculture- } \\
\text { multidisciplinary }\end{array}$ & Finland \\
\hline $\begin{array}{l}\text { Total antioxidant capacity...by Wang et al., J Agric Food Chem. } \\
\text { 1996;44:701-05 }\end{array}$ & 2.82 & 844 & Article & $\begin{array}{l}\text { Agriculture- } \\
\text { multidisciplinary }\end{array}$ & USA \\
\hline $\begin{array}{l}\text { Standardized methods for... by Prior et al., J Agric Food Chem. } \\
\text { 2005;53:4290-302 }\end{array}$ & 2.82 & 802 & Article & $\begin{array}{l}\text { Agriculture- } \\
\text { multidisciplinary }\end{array}$ & USA \\
\hline Development of reliable...by Paran et al., Theor Appl Genet. 1993;85:985-93 & 3.30 & 790 & Article & Agronomy & USA \\
\hline Organic acids in the rhizosphere....by Jones, DL, Plant Soil. 1998;205:25-44 & 2.73 & 774 & Review & Agronomy & Wales \\
\hline Studies on adsorption... by Crini, G, Bioresource Technol. 2006;90:93-98 & 4.98 & 721 & Review & $\begin{array}{l}\text { Agricultural } \\
\text { engineering }\end{array}$ & France \\
\hline $\begin{array}{l}\text { Analysis of acrylamide...by Tareke et al., J Agr Food Chem. } \\
\text { 2002;50:4998-5006 }\end{array}$ & 2.82 & 696 & Article & $\begin{array}{l}\text { Agriculture- } \\
\text { multidisciplinary }\end{array}$ & Sweden \\
\hline Fusarium Ear Blight...by Parry et al., Plant Pathol. 1995;44:207-38 & 2.13 & 691 & Review & Agronomy & England \\
\hline Microbial decolorization...by Banat et al., Bioresour Technol. 1996;58:217-27 & 4.98 & 662 & Article & $\begin{array}{l}\text { Agricultural } \\
\text { engineering }\end{array}$ & England/India \\
\hline $\begin{array}{l}\text { Antioxidant activity of various... by Yen et al., J Agric Food Chem. } \\
\text { 1995;43:27-32 }\end{array}$ & 2.82 & 661 & Article & $\begin{array}{l}\text { Agriculture- } \\
\text { multidisciplinary }\end{array}$ & Taiwan \\
\hline $\begin{array}{l}\text { Standardization of procedures... by Licitra et al., Anim Feed Sci Technol. } \\
\text { 1996;57:347-58 }\end{array}$ & 1.69 & 622 & Article & $\begin{array}{l}\text { Dairy and } \\
\text { animal sciences }\end{array}$ & USA/Italy \\
\hline $\begin{array}{l}\text { Development and validation...by Ou et al., J Agric Food Chem. } \\
\text { 2001;49:4619-626 }\end{array}$ & 2.82 & 621 & Article & $\begin{array}{l}\text { Agriculture- } \\
\text { multidisciplinary }\end{array}$ & USA \\
\hline $\begin{array}{l}\text { High level of genetic...by ElMousadik et al., Theor Appl Genet. } \\
\text { 1996;92:832-39 }\end{array}$ & 3.30 & 614 & Article & Agronomy & $\begin{array}{l}\text { France/ } \\
\text { Morocco }\end{array}$ \\
\hline $\begin{array}{l}\text { Oxygen radical absorbing... by Wang et al., J Agric Food Chem. } \\
\text { 1997;45:304-09 }\end{array}$ & 2.82 & 601 & Article & $\begin{array}{l}\text { Agriculture- } \\
\text { multidisciplinary }\end{array}$ & USA \\
\hline
\end{tabular}

Table 9: Preference of journals for publication in agricultural science ( $\geq 68 \%$ of cumulative of total publications)

\begin{tabular}{|c|c|c|c|c|c|c|c|}
\hline Rank & Journal & IF 2011 & TP & Percentage of TP & $\mathrm{TC}$ & Percentage of TC & ACP \\
\hline 1 & J Agr Food Chem & 2.82 & 23398 & 8.24 & 478472 & 16.01 & 20.45 \\
\hline 2 & Bioresour Technol & 4.98 & 10072 & 3.55 & 165362 & 5.53 & 16.42 \\
\hline 3 & J Dairy Sci & 2.56 & 9322 & 3.28 & 183462 & 6.14 & 19.68 \\
\hline 4 & J Anim Sci & 2.10 & 8295 & 2.92 & 150257 & 5.03 & 18.11 \\
\hline 5 & Crop Sci & 1.64 & 7758 & 2.73 & 97986 & 3.28 & 12.63 \\
\hline 6 & Indian J Anim Sci & 0.12 & 6773 & 2.38 & 5770 & 0.19 & 0.85 \\
\hline 7 & Plant Soil & 2.73 & 6381 & 2.25 & 126899 & 4.25 & 19.89 \\
\hline 8 & Theor Appl Genet & 3.30 & 6252 & 2.20 & 178730 & 5.98 & 28.59 \\
\hline 9 & Poult Sci & 1.73 & 5969 & 2.10 & 81433 & 2.73 & 13.64 \\
\hline 10 & J Sci Food Agric & 1.44 & 5832 & 2.05 & 74293 & 2.49 & 12.74 \\
\hline 11 & Euphytica & 1.55 & 4721 & 1.66 & 49981 & 1.67 & 10.59 \\
\hline 12 & Commun Soil Sci Plant & 0.51 & 4396 & 1.55 & 23170 & 0.78 & 5.27 \\
\hline 13 & Pesqui Agropecu Bras & 0.76 & 4269 & 1.50 & 13494 & 0.45 & 3.16 \\
\hline
\end{tabular}

Contd... 
Table 9: Contd...

\begin{tabular}{|c|c|c|c|c|c|c|c|}
\hline Rank & Journal & IF 2011 & TP & Percentage of TP & TC & Percentage of TC & ACP \\
\hline 14 & Indian J Agric Sci & 0.17 & 4171 & 1.47 & 3694 & 0.12 & 0.89 \\
\hline 15 & Asian Austral J Anim & 0.58 & 4032 & 1.42 & 12874 & 0.43 & 3.19 \\
\hline 16 & Agron J & 1.79 & 3684 & 1.30 & 53369 & 1.79 & 14.49 \\
\hline 17 & Anim Feed Sci Technol & 1.69 & 3327 & 1.17 & 41353 & 1.38 & 12.43 \\
\hline 18 & Small Rumin Res & 1.30 & 3304 & 1.16 & 25318 & 0.85 & 7.66 \\
\hline 19 & Agric Ecosyst Environ & 3.00 & 3281 & 1.15 & 61604 & 2.06 & 18.78 \\
\hline 20 & Anim Reprod Sci & 1.75 & 3047 & 1.07 & 37680 & 1.26 & 12.37 \\
\hline 21 & Crop Prot & 1.40 & 2836 & 1.00 & 26041 & 0.87 & 9.18 \\
\hline 22 & Biomass Bioenergy & 3.65 & 2827 & 1.00 & 44802 & 1.50 & 15.85 \\
\hline 23 & Cereal Res Commun & 0.39 & 2813 & 0.99 & 6694 & 0.22 & 2.38 \\
\hline 24 & Appl Anim Behav Sci & 1.92 & 2763 & 0.97 & 43255 & 1.45 & 15.66 \\
\hline 25 & Weed Technol & 1.21 & 2757 & 0.97 & 23400 & 0.78 & 8.49 \\
\hline 26 & Can J Plant Sci & 0.61 & 2580 & 0.91 & 14932 & 0.50 & 5.79 \\
\hline 27 & Field Crop Res & 2.47 & 2570 & 0.90 & 39824 & 1.33 & 15.50 \\
\hline 28 & Reprod Domest Anim & 1.36 & 2477 & 0.87 & 12871 & 0.43 & 5.20 \\
\hline 29 & Agric For Meteorol & 3.39 & 2438 & 0.86 & 58957 & 1.97 & 24.18 \\
\hline 30 & Am J Agric Econ & 1.17 & 2390 & 0.84 & 27240 & 0.91 & 11.40 \\
\hline 31 & Agric Water Manage & 2.00 & 2370 & 0.83 & 25674 & 0.86 & 10.83 \\
\hline 32 & Anim Genet & 2.40 & 2358 & 0.83 & 26568 & 0.89 & 11.27 \\
\hline 33 & Plant Breed & 1.60 & 2242 & 0.79 & 21474 & 0.72 & 9.58 \\
\hline 34 & Weed Sci & 1.73 & 2228 & 0.78 & 31022 & 1.04 & 13.92 \\
\hline 35 & Eur J Plant Pathol & 1.41 & 2209 & 0.78 & 27054 & 0.91 & 12.25 \\
\hline 36 & Postharvest Biol Technol & 2.41 & 2200 & 0.77 & 38724 & 1.30 & 17.60 \\
\hline 37 & Pest Manage Sci & 2.25 & 2177 & 0.77 & 24653 & 0.82 & 11.32 \\
\hline 38 & Plant Pathol & 2.13 & 2118 & 0.75 & 26249 & 0.88 & 12.39 \\
\hline 39 & Br Poul Sci & 1.01 & 2068 & 0.73 & 24056 & 0.81 & 11.63 \\
\hline 40 & Cienc Rural & 0.43 & 2047 & 0.72 & 1578 & 0.05 & 0.77 \\
\hline 41 & Ital J Anim Sci & 0.34 & 2036 & 0.72 & 2182 & 0.07 & 1.07 \\
\hline 42 & Livest Sci & 1.51 & 1989 & 0.70 & 8244 & 0.28 & 4.14 \\
\hline 43 & Ann Appl Biol & 2.18 & 1951 & 0.69 & 18509 & 0.62 & 9.49 \\
\hline 44 & Soil Sci Plant Nutr & 1.02 & 1950 & 0.69 & 12222 & 0.41 & 6.27 \\
\hline 45 & Ind Crop Prod & 2.47 & 1763 & 0.62 & 17049 & 0.57 & 9.67 \\
\hline 46 & Genet Resour Crop Evol & 1.55 & 1736 & 0.61 & 13791 & 0.46 & 7.94 \\
\hline 47 & Cienc Agrotec & 0.53 & 1692 & 0.60 & 2531 & 0.08 & 1.50 \\
\hline 48 & Can J Anim Sci & 0.77 & 1669 & 0.59 & 13261 & 0.44 & 7.95 \\
\hline 49 & Biosyst Eng & 1.35 & 1663 & 0.59 & 13153 & 0.44 & 7.91 \\
\hline 50 & J Agric Sci & 2.04 & 1612 & 0.57 & 16818 & 0.56 & 10.43 \\
\hline
\end{tabular}

Table 10: Distribution of publications and citations as per impact factor

\begin{tabular}{|c|c|c|c|c|c|c|}
\hline Impact factor (JCR 2011) & Total journals & TP & TC & Percentage of TP & Percentage of TC & ACP \\
\hline 0.01 to $<1.00$ & 121 & 90070 & 249282 & 31.70 & 8.34 & 2.77 \\
\hline 1.00 to $<2.00$ & 57 & 92663 & 927899 & 32.62 & 31.05 & 10.01 \\
\hline 2.00 to $<3.00$ & 20 & 74547 & 1282279 & 26.24 & 42.91 & 17.20 \\
\hline 3.00 to $<4.00$ & 7 & 15481 & 348248 & 5.45 & 11.65 & 22.50 \\
\hline 4.00 to $<5.20$ & 2 & 10466 & 179963 & 3.68 & 6.02 & 17.20 \\
\hline Without IF & 3 & 876 & 604 & 0.31 & 0.02 & 0.69 \\
\hline Total & 210 & 284103 & 2988275 & 100.00 & 100.00 & 10.52 \\
\hline
\end{tabular}

$\mathrm{JCR}=$ Journal citation reports, $\mathrm{TP}=$ Total publications, $\mathrm{TC}=$ Total citations, $\mathrm{ACP}=$ Average citations per publication, $\mathrm{IF}=\mathrm{Impact}$ factor

Science database using the scientometric techniques. The in 2012, which may be attributed to input time-lag in the study reveals an exponential growth of literature except database. This reflects the extensive worldwide study on 
agricultural science. An average $6.55 \%$ of annual growth of publications was observed.

Among 172 countries involved in research in agricultural science. USA topped the list with 69,636 publications followed by India with 22,615 publications, Brazil with 16,221 publications, Peoples R China with 15,751 publications, Canada with 15,206 publications, Japan with 15,150 publications, Germany with 14,882 publications and Spain with 13,663 publications.

The analysis shows that there have been significant changes in terms of the number of publications and citations in various countries. The study also examined the characteristics of qualitative measures such as ACP, AIF, PEI and SI. It is revealed from the data that most of the Asian countries such as India, Peoples R China, Japan and south Korea have contributed significantly in terms of the number of publications but failed to garner more number of citations and lagged behind the USA, Canada and European countries (except Israel) in terms of ACP, AIF, PEI and SI.

\section{REFERENCES}

1. Balasubramanian $P$, Ravanan C. Scientometric analysis of agriculture literature: A global perspective. Libr Prog 2011;31:1-18.

2. Arunachalan $S$, Umarani $K$. Mapping agricultural research in India: A profile based on CAB abstracts 1998. Inf Today Tomorrow 2011;20:9-17.

3. Bartol T. Scientometric assessment of publishing patterns and performance indicators in agriculture in the JCEA member countries. J Cent Eur Agric 2010;11:1-10.

4. Damodharan T. Growth of doctoral dissertations on groundnut in India: A study. Ann Libr Sci Documentation 1998;45:32-8.

5. Garg KC, Kumar S, Lal K. Scientometric profile of Indian agricultural research as seen through science citation index expanded. Scientometrics 2006;68:51-166.

6. Gupta BM. Ranking of Indian institutions in agricultural and allied sciences for their research output during 1999-2008. Ann Libr Inf Stud 2011;58:63-70.

7. Krishna KM, Kumar S. Authorship trends in agriculture research: A bibliometric analysis. Sarada Ranganathan Endowment Libr Sci $J$ Inf Manage 2004;41:229-34.

8. Nasir AM, Hassan H, Hamid KA, Agha SS. Bibliometric evaluation of agricultural literature published in Malaysia. Scientometrics 1994;29:191-217.

9. Kademani BS, Kumar V, Sagar A, Kumar A. Scientometric dimensions of nuclear science and technology research in India: A study based on INIS (1970-2002) database. Malays J Libr Inf Sci 2006;11:21-46.

10. Kademani BS, Kumar V, Sagar A, Kumar A, Mohan L, Surwase G. Scientometric dimensions of thorium research in India. DESIDOC Bull Inf Technol 2006;26:9-25.
11. Kademani BS, Kumar V, Sagar A, Kumar A. World literature on thorium research: A scientometric study based on science citation index. Scientometrics 2006;29:347-64.

12. Kademani BS, Sagar A, Kumar V, Gupta BM. Mapping of Indian publications in $S$ and $\mathrm{T}$ : A scientometric analysis of publications in science citation index. DESIDOC Bull Inf Technol 2007; $27: 17-34$

13. Kademani BS, Kumar A, Sagar A, Kumar V. Scientometric mapping of vacuum research in nuclear science and technology: A global perspective. J Phys Conf Ser 2008;114:012054

14. Kademani BS, Surwase G, Bhanumurthy K. Zirconium research in nuclear science and technology: A scientometric perspective. Int J Nucl Knowl Manage 2011;5:386-401.

15. Kademani BS, Prakasan ER, Sagar A, Mohan L, Kumar A, Bhaskar N, et al. Research trends in fusion engineering: A global perspective. Int J Nucl Knowl Manage 2011;5:307-33.

16. Kademani BS, Sagar A, Bhanumurthy K. Research and impact of materials science publications in India: 1999-2008. Malays J Libr Inf Sci 2011;16:63-82.

17. Kademani BS, Sagar A, Surwase G, Bhanumurthy K. Publication trends in materials science: A global perspective. Scientometrics 2013;94:1275-95.

18. Kademani BS, Surwase G, Sagar A, Bhanumurthy K. Thorium dioxide $\left(\mathrm{ThO}_{2}\right)$ as a nuclear fuel: A scientometric analysis. Int $\mathrm{J}$ Nucl Knowl Manage 2013;6:111-25.

19. Kademani BS, Surwase G, Sagar A, Mohan L, Bhanumurthy K. Research trends in radioactive waste management: A global perspective. Int J Low Radiat 2013;9:59-94.

20. Sagar A, Kademani BS, Kumar V. Scientometric mapping of mass spectrometry research in nuclear science and technology: A global perspective. $12^{\text {th }}$ ISMAS Symposium cum Workshop on Mass Spectrometry, March 25-30 2007, Cidade de Goa Dona Paula Paper No IT-8. p. 1-16.

21. Sagar A, Kademani BS, Kumar V. Research trends in neutron activation analysis in nuclear science and technology: A global perspective. Int J Low Radiat 2009;6:119-46.

22. Sagar A, Kademani BS, Garg RG, Kumar V. Research trends in Cobalt-60 in nuclear science and technology. Int $\mathrm{J} \mathrm{Nucl} \mathrm{Knowl}$ Manage 2010;4:146-64.

23. Sagar A, Kademani BS, Bhanumurthy K. Research trends in nuclear science and technology in India. $2^{\text {nd }}$ International Conference on Asian Nuclear Perspectives, 11-13 October, 2010, Chennai (India); 2010. p. 146-64.

24. Guan J, Ma MA. Bibliometric study of China's semiconductor literature compared with other major Asian countries. Scientometrics 2007;70:107-124.

25. Gall E, Millot G, Neubauer C. Research priorities in Europe: Scientometric and budget analyses of some national and European research priorities. STACS; 2009. p. 1-36.

26. Ortner HM. The impact factor and other performance measures-much used with little knowledge about. Int J Refract Metals Hard Mater 2010;28:559-66.

27. Kademani BS, Kumar V, Ganesh S, SagarA, Mohan L, Kumar A, et al. Research and citation impact of publications by the chemistry division at Bhabha atomic research centre. Scientometrics 2007;71:25-57.

How to cite this article: Sagar A, Kademani BS, Bhanumurthy K. Research trends in agricultural science: A global perspective. J Sci Res 2013;2:185-201

Source of Support: Nil, Conflict of Interest: None declared 